\title{
KREATIVITAS SISWA SMP DALAM MENYELESAIKAN SOAL MATEMATIKA OPEN-ENDED DITINJAU DARI EFIKASI DIRI
}

\author{
Eka Familia Meiningtyas \\ Pendidikan Matematika, Fakultas Matematika dan Ilmu Pengetahuan Alam, Universitas Negeri Surabaya \\ e-mail : ekameiningtyas@mhs.unesa.ac.id \\ Ismail \\ Pendidikan Matematika, Fakultas Matematika dan Ilmu Pengetahuan Alam, Universitas Negeri Surabaya \\ e-mail : ismail@unesa.ac.id
}

\begin{abstract}
Abstrak
Kreativitas adalah salah satu kemampuan inovasi yang dibutuhkan pada abad 21. Hal inilah yang menjadikan kreativitas menjadi syarat untuk tetap dilatih dan dibiasakan pada setiap individu. Kreativitas juga perlu ditekankan pada pembelajaran matematika. Alasan mengapa kreativitas perlu ditekankan adalah siswa dapat menemukan solusi-solusi asli saat memecahkan masalah. Selain itu matematika terlalu kompleks dan luas jika harus diajarkan dengan hafalan..Salah satu cara yang dapat dilakukan adalah membiasakan siswa dengan memberikan soal yang menuntut siswa untuk mengeluarkan seluruh ide kreatif yang dimiliki. Soal openended merupakan salah satu tipe soal yang dapat digunakan untuk mengetahui kreativitas siswa. Soal openended adalah pertanyaan yang memiliki beberapa cara untuk meyelesaikannya. Akan tetapi pertanyaan terbuka tidak menerima setiap jawaban yang diberikan oleh siswa. Pertanyaan terbuka menuntut siswa untuk mampu bepikir rasional tentang alasan-alasan yang digunakan untuk menjawab pertanyaan. Di samping itu, kinerja seseorang dalam matematika juga dipengaruhi oleh efikasi diri. Efikasi diri adalah keyakinan seseorang tentang kemampuan diri yang mampu mempengaruhi seseorang dalam bertingkah laku dan upayaupaya yang dilakukan ketika menghadapi suatu masalah. Penelitian ini merupakan penelitian deskriptif yang bertujuan untuk mendeskripsikan kreativitas siswa SMP dalam menyelesaikan soal matematika open-ended ditinjau dari efikasi diri. Penelitian ini dilaksanakan di SMPIT Al Uswah Surabaya. Subjek penelitian ini adalah siswa kelas VIII yang berjumlah 63 siswa. Instrumen pada penelitian ini adalah peneliti, angket efikasi diri, dan soal matematika open-ended. Teknik analisis data pada penelitian ini adalah analisis hasil tes kreativitas siswa, pengelompokan data, dan perhitungan data. Hasil penelitian menunjukkan bahwa pada kategori efikasi diri tinggi terdapat tujuh siswa dengan tingkat kreativitas sangat kreatif yang mampu memenuhi indikator kefasihan, fleksibilitas, dan kebaruan. Pada tingkat kreativitas kreatif, 7 siswa mampu menunjukkan indikator kefasihan dan kebaruan, sedangkan satu siswa mampu menunjukkan indikator kefasihan dan fleksibilitas. Pada tingkat kreativitas cukup kreatif tiga siswa mampu menunjukkan indikator kebaruan. Pada tingkat kreativitas kurang kreatif, tiga puluh satu menunjukkan indikator kefasihan. Pada tingkat kreativitas tidak kreatif, tujuh siswa tidak mampu menunjukkan indikator kreativitas. Sedangkan hasil penelitia pada kategori efikasi diri rendah terdapat satu siswa dengan tingkat kreativitas sangat kreatif yang mampu menunjukkan indikator kreativitas, yaitu kefasihan, fleksibilitas, dan kebaruan. Pada tingkat kreativitas cukup kreatif, satu siswa mampu menunjukkan indikator kebaruan. Pada tingkat kreativitas kurang kreatif, dua siswa mampu menunjukkan indikator kefasihan. Pada tingkat kreativitas tidak kreatif, tiga siswa tidak mampu menunjukkan indikator kreativitas.
\end{abstract}

Kata Kunci : Kreativitas, Open-ended, Efikasi Diri

\begin{abstract}
Creativity is one of the innovation capabilities needed in the 21 st century. This is makes creativity a requirement to remain trained and accustomed to each individual. Creativity also needs to be emphasized in mathematics learning. The reason why creativity needs to be emphasized is that students can find original solutions when solving problems. Besides that mathematics is too complex and extensive if it must be taught by memorization. One way that can be done is to familiarize students with giving questions that require students to issue all the creative ideas they have. Open-ended questions are one type of question that can be used to determine student creativity. Open-ended questions are questions that have several ways to solve them. However, open questions do not accept every answer given by students. Open questions require students to be able to think rationally about the reasons used to answer questions. Also, a person's performance in mathematics is also influenced by self-efficacy. Self-efficacy is a person's belief in one's ability to be able to influence someone in behaving and the efforts taken when facing a problem. This research
\end{abstract}


is a descriptive study that aims to describe the creativity of junior high school students in solving open-ended math problems in terms of self-efficacy. This research was conducted at SMPIT Al Uswah Surabaya. The subjects of this study were class VIII students, amounting to 63 students. The instruments in this study were researchers, self-efficacy questionnaires, and open-ended math questions. The data analysis technique in this study is the analysis of student creativity test results, data grouping, and data calculation. The results showed that in the category of high self-efficacy there were seven students with very creative levels of creativity who were able to fulfill indicators of fluency, flexibility, and novelty. At the level of creative creativity, 7 students were able to show indicators of fluency and novelty, while one student was able to show indicators of fluency and flexibility. At a creative level of creativity three students were able to show indicators of novelty. At the level of creativity is less creative, thirty-one shows indicators of fluency. At the level of non-creative creativity, seven students were unable to show indicators of creativity. While the results of research on the category of low self-efficacy there is one student with a very creative level of creativity who is able to show indicators of creativity, namely fluency, flexibility, and novelty. At the level of creativity is quite creative, one student is able to show indicators of novelty. At the level of creativity that is less creative, two students are able to show fluency indicators. At the level of non-creative creativity, three students were unable to show indicators of creativity.

Keywords: Creativity, Open-ended, Self-Efficacy

\section{PENDAHULUAN}

Salah satu tujuan pendidikan di Indonesia adalah mampu mengembangkan peserta didik menjadi manusia kreatif yang dapat bertahan pada perkembangan zaman (UndangUndang Nomor 20, 2003). Sehingga individu dapat bersaing dengan dunia luar. Untuk mencapai hal tersebut yang diperlukan saat ini adalah kemampuan untuk menciptakan ide atau gagasan baru yang diperoleh dari kemampuan berpikir kreatif dari masing-masing individu.

Kemampuan inovasi dan kreativitas juga dibutuhkan untuk bekerja pada abad 21. Hal ini sejalan dengan Partnership for 21st Century Learning (P21)(2009) yang menyatakan bahwa kemampuan inovasi yang diperlukan pada abad 21 adalah sebagai berikut, yaitu kreativitas dan inovasi, berpikir kritis dan pemecahan masalah, komunikasi, kolaborasi. Hal ini menunjukkan bahwa kreativitas merupakan syarat untuk memenuhi tantangan di masa depan, sehingga kemampuan berpikir kreatif seharusnya terus dilatih dan dibiasakan.

Menurut Permendikbud No. 20 tahun 2016 tentang Standar Kompetensi Lulusan Pendidikan Dasar dan Menengah, menyatakan bahwa fungsi pendidikan nasional adalah mengembangkan potensi peserta didik menjadi manusia kreatif. Apabila pembelajaran matematika hanya diajarkan dengan metode hafalan saja maka dapat membuat kurang maksimalnya kemampuan siswa. Pembelajaran matematika yang hanya menggunakan konsep hafalan dirasa kurang efektif untuk matematika yang memiliki cakupan yang luas dan kompleks. Menurut Erdogan, dkk (2009) berpendapat bahwa berpikir kreatif adalah gaya pemikiran yang memungkinkan individu untuk menghasilkan produk baru dan autentik, menemukan solusi baru dan mencapai sebuah sistesis. Sehingga membiasakan siswa untuk bepikir kreatif dapat melatih siswa untuk menyelesaikan persoalan dengan ide mereka sendiri.
Kreativitas yang dimiliki siswa diperlukan baik di sekolah maupun dalam kehidupan bermasyarakat. Adapun fakta mengenai pendidikan di Indonesia yang mendukung bahwa kreatifitas perlu diperhatikan yaitu data hasil riset oleh Florida, dkk (2015) yang menunjukkan bahwa GCI (Global Creativity Index) Indonesia menduduki urutan ke115 dari 139 yang diteliti. GCI tersebut mencakup ilmu komputer dan matematika. Hal ini menunjukkan bahwa kreativitas Indonesia masih terbilang rendah.

Berdasarkan uraian di atas, dapat dikatakan bahwa kreativitas Indonesia masih perlu untuk ditingkatkan lagi. Salah satu cara yang dapat digunakan untuk melatih dan meningkatkan kemampuan kreativitas siswa adalah dengan menggunakan model pembelajaran yang menuntut siswa untuk mengeluarkan seluruh ide-ide kreatif yang dimiliki dan juga memberikan soal yang tidak menuntut satu jawaban benar dari siswa. Soal tipe open-ended dapat dijadikan alternative untuk mengetahui kreatifitas siswa. Hal ini karena soal tipe open-ended bukan soal yang sekadar menghafal informasi.

Badger dalam (Husain dkk, 2012) berpendapat bahwa pertanyaan terbuka bukanlah bentuk pertanyaan yang menuntut satu jawaban yang benar. Bukan berarti pertanyaan terbuka adalah pertanyaan yang bisa menerima jawaban apa pun. Sebaliknya, pertanyaan terbuka membahas konsep-konsep kunci, proses dan keterampilan yang melampaui instruksi spesifik yang mendefinisikan konten penting. Secara umum, pertanyaan terbuka membutuhkan pemikiran yang kompleks dan menghasilkan berbagai solusi. Sedangkan Yee (2002) menyatakan bahwa soal open-ended dapat menunjukkan kemampuan siswa dalam bentuk laporan terinci tentang bagaimana kreatifitas siswa dapat menyelesaikan persoalan tersebut. Yee (2002) juga berpendapat jika Siswa perlu menghadapi masalah matematika yang menarik dimana mereka dapat beralasan dan menawarkan bukti untuk pemikiran mereka, berkomunikasi dan menyajikan ide-ide 
mereka dalam matematika, dan menemukan koneksi di seluruh matematika serta dalam kehidupan nyata. Hal ini juga sejalan dengan penelitian yang telah dilakukan oleh Becker dan Shimada (dalam Suryadi:2012) menyatakan bahwa penggunaan open-ended mengandung potensi yang sangat besar untuk meningkatkan kualitas pembelajaran matematika.

Namun menurut pengamatan dan penelitian yang dilakukan oleh Fatah dkk. (2016) menunjukkan bahwa siswa tidak terbiasa dengan masalah terbuka. Siswa hanya akrab dengan masalah yang diatur dalam buku pelajaran atau yang diajarkan guru. Oleh karena itu salah satu cara yang dapat digunakan untuk meningkatkan kemampuan siswa dalam menyelesaikan masalah terbuka adalah dengan soal open-ended. Selain itu soal open-ended juga akan menjadi sarana bagi siswa untuk melatih kreativitas, karena sesuai dengan pendapat Bagner (Husein, 2012) soal open-ended tidak hanya menuntut satu jawaban sehingga memberi kesempatan siswa untuk menemukan berbagai alternatif solusi.

Selain kreativitas yang dimiliki siswa, kinerja siswa dalam matematika dapat pula dipengaruhi oleh efikasi diri mereka sendiri. Bandura (dalam Ayotola \& Adedeji, 2009) berpendapat bahwa kemampuan siswa dalam melakukan tugas akademik dapat diprediksi berdasarkan hasil dari efikasi diri. Sejalan dengan pendapat yang telah diungkapkan oleh Bandura (dalam Ayotola \& Adedeji, 2009), pendapat tersebut diperkuat oleh penelitan yang telah dilakukan oleh Hackett dkk. (1983) yang meneliti tentang pengaruh efikasi diri yang dilakukan di sekolah dan juga perguruan tinggi. Dalam hasil penelitiannya menyebutkan bahwa efikasi diri mempengaruhi sesorang dalam memilih dan mengerjakan suatu kegiatan untuk menghilangkan rasa cemas.

Pendapat lain yang juga sejalan dengan pendapat Bandura adalah pendapat dari Schunk. Schunk (2010) berpendapat bahwa keyakinan efikasi diri membantu menentukan berapa banyak usaha seseorang akan mengeluarkan aktivitas, berapa lama mereka tekun saat menghadapi rintangan, dan seberapa ulet mereka akan menghadapi situasi buruk. Jika situasi buruk diibaratkan soal matematika yang menantang, maka hal ini juga berarti bahwa efikasi diri mempengaruhi kinerja yang akan dilakukan sesorang dalam matematika.

Bandura (1994) berpendapat bahwa efikasi diri merupakan kemampuan seseorang dalam menyelasaikan masalah yang mempengaruhi kehidupan. Keberhasilan efikasi diri menentukan bagaimana seseorang merasa, berpikir, memotivasi diri dan berperilaku. Hal ini akan menentukan apakah seseorang akan mencoba tugas tertentu dan seberapa banyak usaha yang akan dilakukan untuk menjalankan tugas-tugas atau soal open-ended yang diberikan. Di tingkat sekolah, kreativitas matematika akan dikaitkan dengan pemecahan masalah yang melibatkan kreativitas (Nadjafikhah \& Yaftian, 2013). Siswa akan diberi kesempatan untuk berjuang dalam menyelesaikan masalah yang dihadapi. Dalam mengahadapi suatu masalah yang melibatkan kreativitas, siswa membutuhkan keyakinan diri atau efikasi diri agar tetap merasa kompeten dan efektif dalam menghadapi situasi yang sulit (Schwarzer dkk, 1997). Sehingga berdasarkan alasan yang telah diuraikan, peneliti menggunakan efikasi diri sebagai tinjauan karena ada hubungan antara efikasi diri dan kreativitas.

Pada penelitian ini, subjek yang akan dipilih adalah siswa SMP kelas VIII. Hal ini karena menurut Syah (2014) ketika seseorang berusia 11 - 15 tahun mereka dianggap sudah memiliki kemampuan untuk mengoordinasikan pengetahuan yang telah didapat baik secara serentak maupun berurutan. Selain itu Syah juga menambahkan bahwa salah satu kemampuan yang telah dimiliki oleh seseorang dalam rentang usia 11 - 15 tahun adalah mampu menggunakan prinsip-prinsip abstrak untuk menyelesaikan sesuatu. Salah satu bidang yang tidak lepas dari prinsip abstrak adalah ilmu matematika.

Berdasarkan uraian latar belakang di atas peneliti tertarik untuk melakukan penelitian yang berjudul kreativitas siswa SMP dalam menyelesaikan soal matematika open-ended ditinjau dari efikasi diri..

\section{METODE}

Tujuan penelitian ini adalah untuk mendeskripsikan kreativitas siswa SMP dalam menyelesaikan soal matematika open-ended ditinjau dari efikasi diri. Berdasarkan hal tersebut penelitian pendekatan penelitian yang dilakukan adalah deskriptif. Penelitian ini dilaksanakan di kelas SMPIT Al Uswah Surabaya. Subjek penelitian pada penelitian ini berjumlah 63 orang. Masingmasing siswa diberikan angket efikasi diri dan tes kreativitas berupa soal open-ended. Instrument utama yang digunakan pada penelitian ini adalah peneliti sendiri, dan instrumen pendukung meliputi; angket efikasi diri, tes kreativitas open-ended.

Selanjutnya untuk teknik analisis data meliputi; analisis hasil tes kreativitas siswa, pengelompokan data, dan perhitungan data.

\section{HASIL DAN PEMBAHASAN}

Berikut akan dipaparkan mengenai hasil dan pembahasan pada penelitian ini. Pengambilan data penelitian ini dilakukan pada tanggal 17 Juni 2019, 18 Juni 2019, dan 20 Juni 2019 di SMPIT Al Uswah Surabaya tahun ajaran 2018/2019. Berikut akan disajikan mengenai tabel presentase kreativitas siswa ditinjau dari efikasi diri. 
Table 1. Presentase Kreativitas Siswa Ditinjau dari Efikasi Diri

\begin{tabular}{|c|c|c|}
\hline $\begin{array}{c}\text { Efikasi } \\
\text { diri }\end{array}$ & Kreativitas & Persentase \\
\hline \multirow{5}{*}{$\begin{array}{l}\text { Efikasi diri } \\
\text { tinggi }\end{array}$} & Sangat kreatif & $3,17 \%$ \\
\hline & Kreatif & $3,17 \%$ \\
\hline & Cukup Kreatif & - \\
\hline & Kurang Kreatif & $53,97 \%$ \\
\hline & Tidak Kreatif & $28,57 \%$ \\
\hline \multirow{5}{*}{$\begin{array}{l}\text { Efikasi } \\
\text { Diri } \\
\text { Rendah }\end{array}$} & Sangat kreatif & $1,59 \%$ \\
\hline & Kreatif & - \\
\hline & Cukup Kreatif & - \\
\hline & Kurang Kreatif & $1,59 \%$ \\
\hline & Tidak Kreatif & $7,94 \%$ \\
\hline \multicolumn{2}{|c|}{ Total } & $100 \%$ \\
\hline
\end{tabular}

Kreativitas Subjek Berefikasi Diri Tinggi dalam Menyelesaikan Soal Open-ended

Pembahasan mengenai hasil analisis data kreativitas siswa dalam menyelesaikan soal open-ended ditinjau dari efikasi diri tinggi pada setiap tingkat kreativitas adalah sebagai berikut:

a. Kategori Sangat Kreatif

Berdasarkan tabel 1, dapat diketahui bahwa terdapat 3,17\% siswa masuk pada ketegori efikasi diri tinggi dengan kreativitas sangat kreatif. Siswa pada kategori ini mampu menunjukkan indikator berpikir kreatif yaitu kefasihan, fleksibilitas, dan kebaruan. Siswa memenuhi indikator kefasihan karena mampu menunjukkan atau membuat lebih dari dua jawaban percobaan yang berbeda untuk menggambar tower baru yang memiliki tinggi 36 meter dan juga benar. Benar disini berarti sesuai dengan syarat dan ketentuan yang ada pada soal. Hal ini sesuai dengan pendapat Bandura (1982) yang menyatakan bahwa karakteristik seseorang dengan efikasi diri tinggi adalah menyegerakan banyak usaha. Pada indikator fleksibilitas, siswa mampu menyebutkan dua hingga tiga cara untuk mencari tinggi persegi panjang dan segienam. Hal tersebut sesuai dengan ciri seseorang dengan efikasi diri tinggi yaitu mampu mengembangkan gagasan, cara atau ide yang dimiliki melalui pengalaman baru yang belum pernah didapatkan (Djalali, dkk., 2012). Untuk indikator kebaruan, siswa mampu menunjukkan keaslian ide yang digunakan untuk menyelesaikan soal. Hal tersebut karena masingmasing dari siswa menggunakan cara yang tidak biasa digunakan untuk menyelesaikan soal seperti yang sudah disebutkan.

b. Kategori Kreatif

Berdasarkan tabel 1 , dapat diketahui bahwa terdapat $3,17 \%$ siswa masuk pada ketegori efikasi diri tinggi dengan kreativitas kreatif. Siswa dikatakan kreatif apabila mampu menenuhi indikator kefasihan dan kebaruan atau kefasihan dan fleksibilitas. Pada indikator kefasihan, siswa mampu menunjukkan dua gambar tower yang berbeda dan benar. Pada indikator fleksibilitas, kedua siswa yang mampu menunjukkan cara untuk mencari tinggi persegi panjang dan segienam menggunakan SPLDV. Hal ini sesuai dengan sifat seseorang dengan efikasi diri tinggi yang mampu mengeluarkan banyak usaha terhadap tugas yang dihadapi (Bandura, 1986). Sedangkan, cara yang digunakan siswa untuk menyelesaikan soal termasuk cara yang sudah biasa digunakan, sehingga tidak memenuhi indikator kebaruan.

\section{c. Kategori Kurang Kreatif}

Berdasarkan tabel 1, dapat diketahui bahwa terdapat $53,97 \%$ siswa masuk pada ketegori efikasi diri tinggi dengan kreativitas kurang kreatif. Siswa dikatakan kurang kreatif apabila hanya menenuhi indikator kefasihan saja. Siswa dikatakan fasih jika mampu menyebutkan minimal dua jawaban (gambar tower) yang berbeda dan benar. Terdapat satu siswa yang mampu menyebutkan tiga tower berbeda dan benar, tiga puluh siswa mampu menyebutkan dua tower berbeda dan benar, dan tiga siswa lainnya mampu menyebutkan dua gambar tower dengan menunjukkan satu cara. Untuk siswa yang mampu menunjukkan cara yang digunakan, tidak memenuhi indikator kefasihan karena siswa dikatakan fasih jika mampu menunjukkan du acara yang berbeda dan benar. Sementara tiga siswa tersebut hanya mampu menyebutkan satu cara. Begitu juga untuk indikator kebaruan, karena cara yang digunakan sudah biasa atau sering digunakan maka siswa belum dapat dikatakan memenuhi indikator kebaruan. Hal tersebut tidak sesuai dengan pendapat Bandura (1982) yang menyatakan bahwa karakteristik seseorang dengan efikasi diri tinggi adalah menyegerakan banyak usaha dan bersedia mencoba hal baru.

\section{d. Kategori Tidak Kreatif}

Berdasarkan tabel 1, dapat diketahui bahwa terdapat $28,57 \%$ siswa masuk pada ketegori efikasi diri tinggi dengan kreativitas tidak kreatif. Siswa dikatakan tidak kreatif apabila tidak mampu menenuhi salah satu dari tiga indikator kreativitas. Pada kategori ini, terdapat 8 siswa dengan satu jawaban (gambar tower) yang benar, 4 siswa dengan dua jawaban (gambar tower) tetapi hanya satu jawaban yang benar, serta 6 siswa dengan jawaban (gambar tower) yang digambar tidak sesuai dengan jawaban (gambar tower) yang diminta pada soal. Hal ini tidak sesuai dengan pendapat Bandura (1986) yang menyatakan bahwa seseorang dengan efikasi diri tinggi akan mampu fokus 
memperhatikan dan mengeluarkan banyak usaha terhadap tugas yang dihadapi.

\section{Kreativitas Subjek Berefikasi Diri Rendah dalam} Menyelesaikan Soal Open-ended .

Pembahasan mengenai hasil analisis data kreativitas siswa dalam menyelesaikan soal open-ended ditinjau dari efikasi diri rendah pada setiap tingkat kreativitas adalah sebagai berikut:

\section{a. Kategori Sangat Kreatif}

Berdasarkan tabel 1, dapat diketahui bahwa terdapat $1,59 \%$ siswa masuk pada ketegori efikasi diri rendah dengan kreativitas sangat kreatif. Siswa pada kategori ini mampu menunjukkan indikator berpikir kreatif yaitu kefasihan, fleksibilitas, dan kebaruan. Siswa memenuhi indikator kefasihan karena mampu menunjukkan atau membuat dua jawaban (gambar tower baru) yang memiliki tinggi 36 meter dan juga benar. Benar disini berarti sesuai dengan syarat dan ketentuan yang ada pada soal. Pada indikator fleksibilitas, siswa memiliki perhatian pada penyelesaian masalah. Hal tersebut didukung dengan siswa mampu menyebutkan dua cara untuk mencari tinggi persegi panjang dan segienam, yaitu perbandingan dan SPLDV. Hal tersebut tidak sesuai dengan ciri seseorang dengan efikasi diri rendah yaitu cenderung mengalihkan perhatian dari penyelesaian yang mungkin diperoleh (Bandura, 1986). Untuk indikator kebaruan, siswa memenuhi indikator kebaruan karena mampu menunjukkan pada lembar jawaban mengenai cara asli dari diri sendiri yang digunakan untuk menyelesaikan soal, dan cara yang digunakan merupakan cara yang tidak biasa digunakan.

b. Kategori Kurang Kreatif

Berdasarkan tabel 1, dapat diketahui bahwa terdapat $1,59 \%$ siswa masuk pada ketegori efikasi diri rendah dengan kreativitas kurang kreatif. Siswa dikatakan kurang kreatif jika memenuhi indikator fleksibel. Pada indikator fleksibilitas siswa hanya mampu menunjukkan dua tower dengan tinggi 36 meter. Siswa tidak memunculkan langkah atau cara yang dapat digunakan untuk menyelesaikan soal tersebut. Hal itu sesuai dengan pendapat Rahmati (2015) bahwa seseorang dengan efikasi diri rendah memahami peristiwa yang lebih sulit dan menunjukkan depresi, tekanan, dan wawasan yang rendah tentang cara terbaik untuk memecahkan masalah.

c. Kategori Tidak Kreatif

Berdasarkan tabel 1, dapat diketahui bahwa terdapat 7,94\% siswa masuk pada ketegori efikasi diri rendah dengan kreativitas tidak kreatif. Siswa dikatakan tidak kreatif jika tidak mampu menunjukkan memenuhi salah satu indikator kreativitas. Dari lima siswa yang masuk dalam kelompok efikasi diri rendah tidak kreatif, dua siswa hanya mampu menunjukkan satu tower dengan benar, tiga siswa lainnya mampu menunjukkan dua gambar tower yang berbeda tetapi tidak benar. Hal itu sesuai dengan pendapat Kisti dan Fardana (2012) jika siswa dengan efikasi diri rendah maka siswa tersebut cenderung kurang kreatif.

\section{PENUTUP}

\section{Simpulan}

Berdasarkan analisis data yang diperoleh, maka dapat dideskripsikan tentang kreativitas siswa dalam menyelesaikan soal open-ended ditinjau dari efikasi diri siswa adalah sebagai berikut: (1) Dalam menyelesaikan soal open-ended siswa efikasi diri tinggi terbagi menjadi empat tingkat kreativitas, yaitu sangat kreatif $(3,17 \%)$, kreatif (3,17\%), kurang kreatif $(53,97 \%)$, dan tidak kreatif (28,57\%). Dalam tingkat kreativitas sangat kreatif, 2 siswa mampu memenuhi indikator kefasihan, fleksibilitas, dan kebaruan. Pada tingkat kreativitas kreatif, 2 siswa mampu menunjukkan indikator kefasihan dan fleksibilitas. Pada tingkat kreativitas kurang kreatif, 34 siswa menunjukkan hanya indikator kefasihan. Pada tingkat kreativitas tidak kreatif, 18 siswa tidak mampu menunjukkan indikator kreativitas. (2) Dalam menyelesaikan soal open-ended siswa efikasi diri rendah terbagi menjadi tiga tingkat kreativitas, yaitu sangat kreatif $(1,59 \%)$, kurang kreatif $(1,59 \%)$, dan tidak kreatif $(7,94 \%)$. Dalam tingkat sangat kreatif satu siswa mampu menunjukkan indikator kreativitas, yaitu kefasihan, fleksibilitas, dan kebaruan. Pada tingkat kreativitas kurang kreatif, dua siswa mampu menunjukkan indikator kefasihan. Pada tingkat kreativitas tidak kreatif, lima siswa tidak mampu menunjukkan indikator kreativitas.

\section{Saran}

Berdasarkan hasil penelitian dan diskusi penelitian, maka peneliti memberikan saran sebagai berikut. (1) Pada penelitian ini, siswa berefikasi diri tinggi dengan kreativitas kurang kreatif memiliki persentase yang paling besar dari kategori yang telah ditentukan yaitu sebesar 53,97\%. Oleh karena itu, guru perlu memperhatikan lebih siswa yang memiliki efikasi diri tinggi namun kurang kreatif dalam menyelesaikan soal open-ended . (2) Bagi peneliti lain apabila ingin melakukan penelitian yang sejening terkait dengan kreativitas yang ditinjau dari efikasi diri, agar meneliti pada subjek dengan jenjang kelas yang berbeda atau menggunakan tinjauan yang lain, seperti jenis kelamin, jenis kecerdasa, gaya belajar, atau tinjauan yang lainnya.

\section{DAFTAR PUSTAKA}

Ayotola, A., \& Adedeji, T. (2009). The relationship between mathematics selfefficacy and achievement in 
mathematics. Procedia-Social and Behavioral Sciences, 1(1), 953-957.

Badger, E., \& Thomas, B. (1992). Open-ended questions in reading. Practical assessment, research \& evaluation, 3(4), 03.

Bandura, A. (1994). Self-efficacy. In V. S. Ramachaudran (Ed.), Encyclopedia of human behavior (Vol. 4, pp. 7181). New York: Academic Press. (Reprinted in H. Friedman [Ed.], Encyclopedia of mental health. San Diego: Academic Press, 1998).

Bandura, A. (1982). Self Efficacy Mecanism in Human Agency. American Psychologist.

Bandura, A. (1986). From thought to action-mechanisms of personal agency. New Zealand Journal of Psychology, 15(1), 1-17.

Djalali, M. A., dkk. (2012). Pola Asuh Orangtua Demokratis, Efikasi-Diri dan Kreativitas Remaja. Persona: Jurnal Psikologi Indonesia, 1(1).

Erdogan, T., dkk. (2009). The Effect of the Van Hiele Model Based Instruction on the Creative Thinking Levels of 6th Grade Primary School Students. Educational sciences: theory and practice, 9(1), 181194

Fatah, A., dkk. (2016). Open-ended Approach: An Effort in Cultivating Students' Mathematical Creative Thinking Ability and Self-Esteem in Mathematics. Journal on Mathematics Education, 7(1), 11-20.

Florida, R., Mellander, C., \& King, K. (2015). The global creativity index 2015. Martin Prosperity Institute

Hackett, Gail, dkk. (1983). "The Relationship of Mathematics Self-Efficacy Expectations to the Selection of Science-Based College Majors". Journal of Vocational Behavior, 23. pp 329 - 345
Husain, H., dkk. (2012). How to construct open ended questions. Procedia-Social and Behavioral Sciences, 60, 456-462.

Nadjafikhah, M., \& Yaftian, N. (2013). The frontage of creativity and mathematical Creativity. ProcediaSocial and Behavioral Sciences, 90, 344-350.

Partnership for 21st Century Skills. (2009). Framework for 21 st century learning.

Peraturan Menteri Pendidikan dan Kebudayaan Republik Indonesia Nomor 20 Tahun 2016 tentang Standar Kompetensi Lulusan Pendidikan Dasar dan Menengah.

Peraturan Menteri Pendidikan dan Kebudayaan Republik Indonesia Nomor 21 Tahun 2016 tentang Standar Isi Pendidikan Dasar dan Menengah.

Rahmati, Z. (2015). The study of academic burnout in students with high and low level of selfefficacy. Procedia-Social and Behavioral Sciences, 171, 49-55.

Schunk, D. H., Pajares, F. (2010). "Self Efficacy Beliefs". Journal of Social and Behavioral Sciences 668- 67

Schwarzer, R., dkk. (1999). Assessment of perceived general self-efficacy on the Internet: Data collection in cyberspace. Anxiety, stress and coping, 12(2), 145161.

Suryadi, Didi. 2012. "Pendidikan Matematika". Ilmu dan Aplikasi Pendidikan. Universitas Pendidikan Indonesia : Imtima

Syah, Muhibbin. (2014). Psikologi Pendidikan dengan Pendekatan Baru. Bandung: Remaja Roesdakarya.

Yee, F. P. (2002). Using short open-ended mathematics questions to promote thinking and understanding. In Proceedings of the 4 th International Conference on The Humanistic Renaissance in Mathematics Education, Palermo, Italy. 